\title{
Comment
}

\section{Playing Without a Full Deck: Scientific Realism and the Cognitive Limits of Legal Theory}

\section{Steve Fuller*}

One of the most widely watched debates in legal theory today concerns whether genuine political community is possible in light of the law's apparent indeterminacy. Not only has this debate occupied skeptics within the profession, such as the members of the Critical Legal Studies movement (CLS), but even a bastion of the liberal establishment like Ronald Dworkin has been pushed to make the tension between community and indeterminacy the focal point of Law's Empire, a book intended for a general, philosophically literate audience. ${ }^{1}$ As the debate has been played out in the law journals, the partisans have marshaled an ever-increasing number of allies from outside the legal profession, especially from the philosophy of science. However, one party quite prominent among philosophers of science has been conspicuously absent from this debate, namely, the scientific realist. I shall argue that, in neglecting the scientific realist, legal theorists have failed to come to grips with the central role that cognitive limitations play in legal reasoning.

An exemplary round of the debate in question was recently conducted by Joseph Singer, a CLS sympathizer, and John Stick, a defender of the liberal order. $^{2}$ Both theorists take comfort in the idea that the law is a product of human decisionmaking. Whereas Singer infers from this idea

\footnotetext{
- Assistant Professor of Philosophy, University of Colorado at Boulder. After September 1, 1988, Assistant Professor, Center for the Study of Science in Society, Virginia Polytechnic Institute.

1. R. DWorkin, Law's EmpIRE (1986). See infra note 13.

2. Singer, The Player and the Cards: Nihilism and Legal Theory, 94 YALE L.J. 1 (1984); Stick, Can Nihilism Be Pragmatic?, 100 Harv. L. Rev. 332 (1986).
} 
the conclusion that the law is always open to change as each generation of decisionmakers sees fit, Stick infers that it is within the power of successive generations of decisionmakers to uphold the same laws (or at least the same values expressed by those laws), thereby allowing a lasting political community to form. Notice that both Singer and Stick presume that the law is under the cognitive and practical control of humans-perhaps in a way that most "naturally occurring" (i.e. non-human) phenomena are not-precisely because it is a creation of humans.

But is the presumption a sound one? Far from being merely a philosopher's question, this one goes to the heart of contemporary legal theory, in particular to the multi-volume project, Politics: $A$ Work in Constructive Social Theory, that has been undertaken by Roberto Unger. ${ }^{3}$ Unger quite explicitly starts with the premise that the social order is either natural and (therefore) beyond human control or created and (therefore) within human control. Unger's mission is to demonstrate that the latter is the case, despite the efforts of political and scientific authoritarians to show otherwise. ${ }^{4}$

By contrast, a legal theorist influenced by scientific realism would see Unger's premise as harboring a false dichotomy. She would observe that the consequences of, say, legal decisionmaking are in principle no more and no less under our control than the effects of some non-human cause. In both cases, our judgment is fallible, even to the point of conceptualizing the relevant phenomena in highly misleading categories that deny us the predictive and explanatory power we seek. Every so often, the scientific realist tells us, inquirers become especially self-conscious about this point and radically shift their categorical framework in order to correct their erroneous ways; hence, the scientific revolutions of Newton over Aristotle and (more interesting for our own purposes) Marx over Smith and Ricardo. Each revolution is the unanticipated, and often unintended, consequence of inquirers pursuing normal science in the old paradigm and run-

3. Three volumes have already been published: R. UNGER, SOCIAL THEORY: ITS STTUATION AND Its Task (1987); False Necessity: Anti-Necessitarian Social Theory in the Service of Radical Democracy (1987); Plasticity into Power: Comparative Historical Studies on THE INSTITUTIONAl Conditions of Economic AND Military Success (1987).

4. Unger acknowledges the major emancipatory role played by liberalism and Marxism in highlighting the constructed character of society. R. UNGER, SOCIAL THEORY, supro note 3, at 1-10. However, as Unger reads the history of the last two centuries, once these political doctrines suffered significant practical setbacks, both theorists and politicians fell back on the idea that society had a life of its own, subject to a narrow range of possible changes, and was thus not amenable to voluntarily undertaken collective action. In this way, then, Unger believes that what he calls "positivism" (roughly, the attempt to study social phenomena as if they were natural) has conspired with atavistic forms of authoritarianism to convince people that there is little they can do to improve their situation. Against these efforts to undermine substantial political action, Unger argues that the reason liberalism and Marxism failed was not that they neglected certain intractable facts about the nature of society, but rather that they did not conceive of society as being within the control of its members. Unger interids his argument to have special relevance to the political options available to third world countries, particularly his native Brazil, where-it is rumored-he plans to return upon the completion of Politics, to work as a political activist. 
ning across too many intractable anomalies along the way: once again, human agency is in less than full control of the consequences of its own activity. $^{5}$

When the paradigm is not only human in origin, but also in object and in application, the stakes may be sufficiently high to inhibit the inquirer from admitting that there are persistent anomalies. As the scientific realist sees it, the ease with which legal theories can function as establishmentarian ideologies-even if it is of a liberal establishment-makes them especially ripe for this sort of diagnosis. Without yet having examined Singer and Stick in detail, the realist can already detect the potential sources of rationalization and systematic self-deception in the contemporary legal theory debates. For his part, Singer draws our attention away from the diverse social consequences of implementing a legal decision back to the intentional states of the original decisionmakers, while Stick converts the history of divergent and often conflicting political traditions in this country into a story of one dominant (and highly reasonable) liberal voice with several distinctly lesser voices in the background. ${ }^{6}$

5. The language here is, of course, taken from T. Kuhn, The Structure of Scientific Revolution (2d ed. 1970). The interpretation, however, is not so much Kuhn's own but that of his principal interlocutor, Karl Popper, who explains the possibility of objective knowledge in terms of our unintentionally generating problems in the course of pursuing our ends. See K. POPPER, OBJECTIVE KNOWLEDGE 106-90 (1972); Popper, The Rationality of Scientific Revolutions, in ScIENTIFIC Revolutions 80 (I. Hacking ed. 1981).

To understand the implications of this deeper sense of human cognitive fallibility for philosophy of science, consider how one might go about explaining the connection between a theory's truth and its acceptance by one or more scientific communities. Since these contexts of acceptance are generally embedded in rather diverse social circumstances, philosophers are inclined to suppose that the theory must have some content or truth that remains invariant across these circumstances. Moreover, philosophers normally assume that invariance of this sort is necessary for the transmission and growth of knowledge. However, all this talk of "invariance" and "continuity" typically confuses the relatively uncontroversial claim that the truth itself does not change with the highly dubious claim that the truth is transmitted intact by reliable linguistic means. Indeed, if it can be shown that the linguistic means at our disposal for transmitting truths are less than reliable, then whatever invariance we seem to find in scientific theories accepted across many socio-historical contexts (e.g., Newtonian mechanics and Darwinian biology) cannot be due to the invariant nature of the truth transmitted, but is rather due to institutionalized cognitive mechanisms that suppress the differences in interpretation that would have naturally resulted from the theory being unreliably transmitted.

In short, then, a theory's truth cannot be the best explanation for its acceptance because such an explanation falsely presupposes that theory can be transmitted intact to the various contexts required for acceptance. Combine this argument with a general acceptance of scientific realism, and the paradox becomes clear: the most persuasive grounds for realism are themselves an artifact of our cognitive fallibility, the depth of which would not have been realized had we not already been committed to realism, and hence to a principled distinction between reality and our knowledge of it.

6. The sort of rationalization attributed here to Singer and Stick is known to Marxists as the reification of history, which involves imputing undue continuity between the past and present, usually for the purpose of legitimation. The locus classicus of Marxist discussions of reification is $G$. LuKacs, History and Glass Consciousness 83-222 (1972). As we shall see in more detail later, Singer accounts for decisionmaking from a purely personalistic standpoint, frequently asking the reader to empathize with what must be going through the judge's mind. See Singer, supra note 2, at 65. The persuasiveness of such an appeal rests on the presumption that there is at least some groundlevel sense of continuity in how people throughout history have experienced the exigencies of the human condition. And while Stick does not adopt the personalistic perspective, he too characterizes legal history as if it had some unfolding purpose, such as the realization of liberal values. But this is not to say that all recent legal theorists reify history. Some are self-conscious about reification and 
So far, a reader with a good ear for the philosophical resonances in the recent legal theory debates will have heard some familiar sounds. Indeed, in delivering her preliminary diagnosis, our scientific realist sounds very much like the sort of Marxist or deconstructionist on whose authority many CLS partisans seem to rely. As I will show in the next section, however, the critical potential of these authorities is not fully realized by operating within what philosophers today call the antirealist framework shared by Singer and Stick. The particular brand of scientific realism that will be presented goes beyond simply postulating a distinction between the world and how we think about it. It also recognizes a difference between our own social constructions and how we think about them.

After showing how a recognition of this difference would alleviate much of Singer's and Stick's inclarity about the nature of indeterminacy in legal decisionmaking, I will draw on recent psychology and sociology of science to identify institutionalized cognitive mechanisms that cause us to suppress any awareness of just how fallible and generally divergent human judgment really is. Finally, I will examine the implications that all this has for political metatheory.

\section{The Need for and Neglect of Scientific Realism}

The easiest way to demonstrate the neglect of scientific realism in the recent legal theory debates is by recounting Singer's own characterization of the three main parties to these debates. The rationalists, with whom Stick identifies, explicitly trace the legitimacy of a legal system to some consensually endorsed foundations, which normally turn out to be a method for determining how a judge ought to rule in specific cases (which is often cast in terms of the judge's ability to secure a determinate meaning from the body of law). Nihilists, the hard-core of CLS, argue that legal systems lack the sort of foundations sought by rationalists and, on that basis, conclude that all such systems are illegitimate. Finally, the $i r$ rationalists, with whom Singer identifies, deny the connection between legitimacy and consensual foundations-but only to assert in its place the role that personal knowledge plays in undergirding the legal system. ${ }^{7}$ All three of these positions are antirealist because their proponents presuppose that it makes no sense to say that a statement is "true" or "false" ("right" or "wrong") unless there is a way of showing that it is one or the other. Rationalists and irrationalists differ over whether the relevant mode of "showing" is communal or personal, while nihilists fail to find any such mode and thereby deny the legitimacy of any legal system.

A tell-tale sign of the antirealism of the three positions is that they all

approach the writing of history with a deconstructive attitude. An exemplary case is Gordon, Critical Legal Histories, 36 Stan. L. Rev. 57 (1984). See infra text accompanying notes 41-47.

7. See Singer, supra note 2, at 3-5; Stick, supra note 2, at 332-38. 
take the perspective of an insider to the legal system in question. This point is perhaps clearest in the cases of the rationalist and the irrationalist, who are clearly arguing over whether the legal decisionmaker needs to go beyond his own conscience to authorize his decision. But the point also applies to the nihilist. After all, nihilism does not merely require the decisionmaker to realize that all the available modes of legitimation are fundamentally false, but it also requires that she draw two further conclusions, namely, (1) that the situation would not improve by the introduction of new modes of legitimation, and (2) that this irremediable illegitimacy leaves the legal system without proper guidance. We see, then, that the nihilist uses her knowledge of the current legal possibilities as the measure of legal reality, which is in step with the antirealist tendency to make verifiability constitutive of validity (or truth). In other words, since the nihilist cannot specify any adequate conditions for legal verification, she infers that the idea of legal validity has been completely undermined. ${ }^{\mathbf{B}}$

By contrast, a legal theorist influenced by scientiric realism would refuse to draw the nihilist's two conclusions, asserting instead the conceptual independence of validity from verifiability. As a result, he would counter the nihilist by arguing that there may indeed be a way of legitimating legal decisions, but it would involve going outside the decisionmaker's current conceptual framework-perhaps even to the point of radically reconceiving the relations between the intentions and the consequences of his decisions. Moreover, even if this better framework is only dimly perceived at present, that fact alone is not enough to detract from the legitimacy of the legal decisions currently being made. To think otherwise would be like envisaging that people moved about the earth less assuredly before they knew what kept them from flying off its face. Of course, once Newtonian mechanics was known, it became possible to control and extend human motion in ways that were previously inconceivable by, for example, systematically compensating for the effects of gravity. Similarly, in the case of the law, a comprehensive explanatory and predictive theory of judicial decisionmaking would provide the means by which decisions in the future could be made to have a more desirable impact on the social order. Clearly, then, the legal theorist influenced by scientific realism speaks as an outsider to the legal system under study, holding out the possibility that there is a way of understanding the system that is better than any insider's. ${ }^{9}$

8. A fascinating history of the influence of nihilism on continental European jurisprudence over the last century is G. Rose, Dialectic of Nihilism: Post-Structuralism and the Law (1984).

9. The difference between insider and outsider perspectives is reminiscent of H.L.A. Hart's distinction between the internal and external points of view from which a rule-governed practice can be examined. See H.L.A. HART, The CoNCEPT of LAw 85-88, 244 (1960). However, my distinctions are drawn to different effect. Hart is interested in showing that even if the outsider, after sustained observation of a society's practices, were able to predict its members' behavior, that alone would not be 
If all that was interesting about scientific realism was its opposition to the viewpoints of the protagonists in the legal theory debates, then a sudden injection of realism would do little more than contribute to an idle sense of completeness. However, scientific realism is interesting for two more substantial reasons, which we shall consider in turn. First, as a matter of sociological fact, realism is the dominant position in contemporary philosophy of science, and its influence has rapidly spread to such seemingly unrelated realms as ethics and aesthetics, which touch on the value issues directly raised by the philosophy of law. ${ }^{10}$ Indeed, the very name of the opposing viewpoint, "antirealism," is a recent coinage that reflects the dialectical disadvantage at which positions formerly known as "idealism" or "positivism" or "instrumentalism" or "phenomenalism" currently find themselves. ${ }^{11}$ The reliance of contemporary legal theorists on the arguments and authority of recent philosophers of science is easy to spot. ${ }^{12}$ Yet

sufficient to capture the normative, obligatory, character that they attach to those practices. Hart's point is that the values which a society invests in its practices cannot be exhaustively captured by a purely behavioral account. He thus presumes that the (normal) insider's self-understanding establishes the standard to which the outsider's knowledge aspires. Consequently, Hart does not consider the possibility that, notwithstanding the values upheld by the insider's understanding of his practices, that understanding might still not permit the insider to predict and explain his own behavior as well as a theory scientifically adduced by the outsider. In this way, she outsider may be able to show that the insider, quite literally, does not know what he is doing. Indeed, as in the case of Marxist theories of ideology and false consciousness, the particular way in which the insider misunderstands his own activities may even serve to keep those practices in place and thereby stabilize the power relations of the society.

10. See, e.g., Images of Science (P. Churchland \& C. Hooker eds. 1985); See, e.g., Scientific REALISM (J. Leplin ed. 1984). For the influence of scientific realism in recent value theory debates, see Moral Realism (N. Gillespie ed. 1986).

Scientific realism gained ascendency in the philosophy of science because it offered a novel and useful perspective on the problem of incommensurability, which had plagued philosophers since Kuhn brought it to everyone's attention. The problem arose in this way. We believe that we ought to be able to say, for example, that Aristotle was wrong about most of the things he said about locomotion. Antirealists believe our criticism would be justified only if locomotion as a concept exist independently of the particular languages in which it was described, so it could provide the (implicit) standard against which descriptions in those languages could be compared.

Kuhn had argued that scientific terms referred only within the conceptual framework in which they were used, that is, that Aristotle's concept of locomotion could only be understood by recreating Aristotle's conceptual framework. See T. KuHN, supra note 5. Kuhn's command to reconstruct Aristotle's framework implied that we ought not evaluate Aristotle's concept of locomotion in terms of its inadequacy within our own conceptual framework. According to Kuhn, then, our criticism of Aristotle was unwarranted. (The compelling logic of his position had troubled philosophers allied with antirealism. See, e.g., R. Garnap, Meaning and Necessity 205-06 (2d ed. 1958) (discussing logical positivism).) Scientific realists argue that the justifiability of our criticizing Aristotle does not depend upon our ability to hold our descriptions of locomotion constant across paradigms. In other words, the realists separate truth from meaning, a move that authorizes criticism of concepts incommensurable with our own. See supra note 5 (describing realist's denial that continuity of concepts implies continuity of description).

11. Oxford philosopher Michael Dummett is perhaps the most distinguished contemporary antirealist spokesman. He has been especially sensitive to having to bear the burden of proof. See $M$. Dummetr, Truth and OTHER ENIGMas 145-65 (1977). Contrast this with Ernest Nagel's presumption that instrumentalism, an antirealist position, had the upper hand. Nagel's view appeared only a generation ago in the most widely used philosophy of science text of the day. E. NAGEL, THE Structure of ScIENCE 106-52 (1960).

12. Singer's distinction between rationalism and irrationalism, as well as his advocacy of irrationalism, is motivated by Richard Rorty's distinction between "normal" and "abnormal" discourses, 
scientific realists are conspicuous by their absence, either as friends or foes. This state of affairs cries out for explanation. ${ }^{13}$ Second, the neglect of scientific realism makes legal theorists oblivious to the liabilities of human

which is, in turn, based on Kuhn's distinction between normal and revolutionary science. See $R$. Rorty, Philosophy and the Mirror of Nature 315-32 (1979); Singer, supra note 2, at 3-5. In addition to Kuhn, Stick draws on Imre Lakatos, Larry Laudan, and Ian Hacking to construct a consensus theory of politics to match the consensualist approach to truth that he sees developing in their work. See Stick, supra note 2, at 332-38.

13. Ronald Dworkin is one of the few recent legal theorists to have modeled his position on a sort of realism. However, in the rush to shove Dworkin into the pragmatist melting pot, his fellow legal theorists have failed to detect the tell-tale signs of his rather distinctive position. Stick is especially guilty of this. See Stick, supra note 2, at 376-83; see also Stick, Literary Imperialism: Assessing the Results of Dworkin's Interpretive Turn in LAw's EMPIRE, 34 UCLA L. REv. 371 (1986).

Dworkin registers his protests to this "pragmatization" of his work in LAw's EMPIRE, supra note 1, at 151-75. First, Dworkin fully agrees with Singer and other defenders of CLS that the law has nothing akin to a verification procedure for judicial decisions, or even standardized definitions of such key concepts as justice, right, obligation, and even law itself. However, unlike the legal antirealists, Dworkin does not as a result suddenly lose a sense of the law's objectivity, nor does he imagine that even antirealist judges lose their intuitions about "better" and "worse" interpretations of cases. Indeed, the fact that the judge's intuitive sense of interpretive constra' its is not undermined by his failure to codify them suggests to Dworkin that these intuitions are getting at something, call them "principles," that transcended the conscious design of the original legislators and probably elude even our own best interpretations, but which nevertheless sustain the law's integrality to an ever-changing society.

In light of his commitment to realism, it should come as no surprise that Dworkin makes his point by distinguishing the actual history of law from an idealized history that would allow us imaginative access to the decisions that judges and legislators would have made, had they acted "on principle" rather than on the basis of more pressing local concerns. Dworkin's moralism finally creeps in, as he accuses of "bad faith" judges who knowingly yielded to contingency when principle would have dictated a different interpretation of the law. See R. DwORKIN, supra note 1, at 225-38, 317-50.

Rather than questioning the existence of the sort of legal principles that Dworkin presupposes, his critics would do better to tackle his moralism separately and thereby question why we should pursue such principles, even assuming that they exist, when they conflict with more immediate demands. CLS would seem to be the natural vantage point for launching this critique, but it too is periodically overcome by moralism. Of course, antirealists can voice just as much moral outrage about inequities in the law as realists can, but they cannot justify their outrage in the same way. For example, an antirealist can complain about judges and legislators violating rules to which they are explicitly held accountable by society - that is $\mathrm{s}_{\mathrm{z}}$ if he is one of Singer's rationalists and not one of his nihilists or irrationalists (see supra note 7). In the case of Singer's latter two categories, the ground becomes much trickier, as may be readily seen by an examination of James Boyle's concept of bias in the law. See Boyle, The Politics of Reason: Critical Legal Theory and Local Social Thought, 133 U. PA. L. REv. 685, 691-707, 746-55 (1985).

If, as Boyle and his fellow nihilists maintain, every court decision is motivated by the judge's particular social interest, then the law is "biased" in the sense that each decision "weighs" in favor of one or another interest. This sense of bias is unproblematic for the nihilist, and is hardly enough to license moral outrage. In fact, CIS generally endorses the appeal to local interests as a demystified way of grounding judicial decisions. However, "bias" also suggests a weighing against-especially against social groups that have been systematically unserved by the law. But while this fact can be easily demonstrated, it is still not sufficient to ground an antirealist's sense of outrage. After all, since no rules were violated in the course of making these biased judgments-indeed, there are no rules-then our legislative options are clear: either we continue as we have or we change what we are doing, but we do not succumb to thinking that the legal system has somehow been "betrayed" by judges acting out of their own interest to the detriment of others. Such a thought, which abounds in CLS, comes dangerously close to presupposing the realist's moral idealization of history and the existence of transcendent principles, about which judges and legislators have definite (albeit inchoate) intuitions. Moreover, the principles that tend to be courted are the ones most often intuited by Dworkin-especially the Platonic idea of justice as the harmonizing of social interests, which at any given moment requires that suppressed interests be compensated at the expense of dominant ones. Thus, instead of trying to shove Dworkin into the pragmatist melting pot, CLS scholars would do better to recognize their own backslide into Dworkin's realism. 
judgment. While Singer and Stick have much to say about such "hot" aspects of judgment as passion and interest, they have little to say about the "cold" aspects which systematically impede reason from reaching its intended destination. ${ }^{14}$ As we shall see, the problem here is that the antirealist tends to reinterpret the evidence that a realist would adduce for the presence of cognitive limitations in ways that undercut the realist's critical purposes. We can best start by considering the two philosophers to whom Singer, Stick, and an increasing number of practitioners of the humanities and social sciences have turned for guidance in matters philosophical: Richard Rorty and Richard Bernstein. ${ }^{15}$

Rorty and Bernstein claim to have diagnosed a malaise that has afflicted all Western philosophers since Descartes, which Bernstein has dubbed the Cartesian Anxiety. ${ }^{18}$ The Cartesian Anxiety haunts one with the belief that one's grip on reality is only as secure as one's knowledge of it. Consequently, the philosopher puts a premium on locating indubitable foundations for knowledge so as to maintain his contact with reality. Two points about the Anxiety are worthy of note. First, it is much more compelling as an account of my own state of knowledge than that of some third party being observed. For while I would start to question my sanity (and hence my grip on reality) if I seriously supposed that most of my own beliefs were false, I would be much less inclined to question the sanity of people in other places and times who held mostly false beliefs. In other words, when I look at other people, I recognize that the rationality of their believing something is not intimately tied to whether or not those beliefs are true. ${ }^{17}$ The second and more germane point is that the Carte-

14. The hot/cold distinction is taken from J. Elster, Making Sense of Marx 459-510 (1985).

15. The principal sources to which they have turned are R. RORTY, supra note 12 , and R. BERNstein, Beyond Objectivism and Relativism: Science, Hermeneutics, and Praxis (1983). Although Rorty and Bernstein are among the most talked about philosophers in this country today, they have had little impact on the professional philosophy establishment. To a large extent, this should come as no surprise, since both authors draw on and align themselves with intellectual trends of continental European origin (especially hermeneutics and deconstruction) whose American home is to be found in liberal arts departments outside philosophy. What is perhaps a little surprising, and very ironic, is that so many theorists in the liberal arts departments (perhaps less so in the law) are rallying behind Rorty and Bernstein as leaders of a movement which their own colleagues have been routinely promoting for at least a generation. This point testifies to the continued image of philosophy as the ultimate legitimating discipline-the very image that Rorty and Bernstein seek to combat!

16. R. BERNSTEIN, supra note 15, at 16-20; Singer, supra note 2, at 5 n.8; Stick, supra note 2, at $336 \mathrm{n} .13,336 \mathrm{n} .15$. Stick thinks that Bernstein is closer to his own position, while he takes Rorty to be closer to Singer's.

17. This point has been used to combat the interpretive skepticism brought on by Kuhn's incommensurability thesis. See supra notes 5 \& 10. For example, Donald Davidson has argued that, given an honest attempt at interpretation, our beliefs about what another person means are bound to be largely correct, simply given the radical implausibility of our own beliefs being largely in error. $D$. DAvidson, Inquiries into TRUTH AND INTERPRETATION (1984). By introducing the difference between insider and outsider perspectives, a Davidsonian hermeneutics can be produced which allows the ethnocentric interpreter-who has confidence that his attribution of false beliefs to others is probably correct-to return with a renewed sense of philosophical respectability. See G. MacDonald \& P. Pettit, Semantics and Social. Science (1981). Now carried to its logical extreme, as Hilary 
sian Anxiety is clearly an affliction from which only antirealists can suffer, because it involves identifying the structure of knowledge with the structure of reality. Moreover, in good Freudian fashion, Bernstein argues that philosophers can never really be cured of the Cartesian Anxiety; rather, they must learn to live with it. Not surprisingly, the sorts of epistemic and political practices that our two diagnosticians recommend remain squarely within the antirealist framework. ${ }^{18}$ Realists, by contrast, avoid the Cartesian Anxiety entirely by learning to think of themselves as the objects of some more advanced knower's observation. ${ }^{19}$

Putnam has proposed that we do, the ethnocentric interpreter would have to become an outsider to himself and thereby confidently claim that most of his own beliefs are probably false. In a manner reminiscent of Popper, Putnam has argued that this self-critical attitude is the hallmark of the scientific realist mind-set! See H. Putnam, Meaning and the Moral Scierices 18-33 (1978).

18. R. BERNSTEIN, supra note 15 , at 19 . Consider some of the more general epistemic-political parallels that legal theorists have picked up from Rorty and Bernstein. Start with the claim that victims of the Cartesian Anxiety wallow in metaphysical chaos, until order has been explicitly introduced by one or more rational agents laying down foundations for knowledge. R. RORTY, supra note 12 , at 155-64; R. BERNSTEIN, supra note 15, at 16-20. The resemilince between this seventeenth century view of knowledge and the view of politics that Hobbes was proposing at the same time is uncanny: An anarchic state of nature obtains until the terms of a social contract are explicitly formulated. On this view, as Jeremy Bentham put it, everything is permitted that is not expressly prohibited. And once the spheres of epistemic and political reason have been circumscribed by the foundations and the contract, respectively, areas of "free play" are implicitly opened up. The area of epistemic free play, or "indeterminacy," is reserved for unverifiable statements and terms whose meanings have yet to be empirically fixed. This is the realm of metaphor, analogy, and other forms of figurative language, which has been the main source of intellectual innovation and experimentation, often leading to a transformation-even revolution-in the epistemic foundations themselves. Pioneering works in this still neglected area include M. Hesse, Models and ANalogies In Science (1966); D. Schon, The Displacement of Concepts (1963). It is to the credit of literary critic I.A. Richards that he jumped on the verificationist bandwagon primarily because of its implications for non-cognitive language. See I.A. RichardS, SPECUlative INSTRUments (1957).

Singer places considerable weight on this constructive side of indeterminacy, whose political equivalent is the freedom to engage in voluntary associations and other locally binding contracts, the success or failure of which can then be used to orient the design of more globally binding legislation. See H.L.A. HART, supra note 9, at 97-119. This brief portrait of the Cartesian Anxiety reiterates that liberal polities is the pursuit of antirealism by other means.

19. This antirealist interpretation of realism has been made in Clark, The Legacy of Skepticism, 69 J. PHIL. 754 (1972).

This is perhaps a good place to discuss the relation of scientific realism to the family of early twentieth century movements known as "legal realism," which shared an interest in establishing an ideal standpoint from which the workings of the legal system can be reliably described. A recent review of the contemporary relevance of this movement is Yablon, Law and Metaphysics, 96 YaLE L.J. 613 (1987).

Despite textbook attempts to sort out the strands of legal realism, see, e.g., M. Golding, PHiLosoPHY OF LAW 37-39 (1975), there has been a tendency among recent theorists to treat the legal realists as an ideologically uniform group, though there is disagreement regarding exactly which ideology they collectively express. See, e.g., Singer, supra note 2, at 48-49; Stick, supra note 2, at 349-50. For our purposes, it is important to discriminate between two strands. The first is represented by Oliver Wendell Holmes' "bad man" theory of law. See Holmes, The Path of the Law, 10 Harv. L. Rev. 456 (1897). Holmes argued that a law is nothing more than a prediction of the punishment that a person is most likely to receive, if he is held responsible for a given wrongdoing. This is clearly the view of law that a lawyer has when advising a potential wrongdoer. Notice that this view, which seems to have been the model of Hart's external standpoint, see H.L.A. HART, supra note 9, at 243, does not involve many of the features of legal realism on which contemporary theorists focus. For example, Holmes does not challenge the transparency of legal language as a means of determining what the law is; rather, he challenges only the view that what is determined by a law is anything more exalted than a regularity governing judicial behavior. Thus Holmes has no need for social scientists, Marxists, or anyone else who might suggest that insiders to the legal system do not possess an 
But how does insensitivity to the realist position prevent legal theorists from recognizing the substantial role played by cognitive limitations? At the outset, it is important to make an obvious point about antirealists: Namely, that they do not deny that we all commit errors and that this is probably an ineradicable feature of our cognitive processes. However, antirealists and realists differ substantially on what is the best explanation of this psychological fact. Whereas the general realist strategy for explaining error is in terms of our beliefs running up against an independently existing reality, the general antirealist strategy explains error in terms of two or more perspectives conflicting over some situation, the resolution of which leads one perspective to be deemed "right" and the others "wrong."

The first point to make about these contrasting explanations is that they instill different attitudes and strategies toward error. Roughly speaking, realists aim for welcomed encounter with error, while antirealists aim for avoidance and containment of error. For a realist, being in error is an opportunity for revising one's theory to get it more in accordance with the nature of reality. For an antirealist, however, the very same state is seen as indicating that one viewpoint has gained legitimacy at the expense of some other viewpoint over a matter of common interest. Sensitive to the heavy authoritarian overtones in this account, an antirealist like Rorty will try then to use his explanation of "error" as the basis for arguing that we ought to restrict the term's usage, relying as much as possible on the mutual tolerance (if not respect) of different perspectives and revealing, where necessary, the power plays that were required for making one perspective seem more acceptable than another. ${ }^{20}$

Notice also that the realist and antirealist are not merely offering contrasting explanations of error, but they also seem to be trying to explain quite different features of error. Realists are concerned with understanding the sort of situation that gives rise to a feeling that something has gone

optimal account of how the system works. Holmes' targets are natural law theorists and others who think that the law is grounded in transcendent values; he seems to have no quarrel with more mundane practitioners of the legal trade.

In order to get into the second debate, one must turn to other legal realists, such as Roscoe Pound, Jerome Frank, Karl Llewellyn, and Joseph Bingham-each of whom proposes a master language (e.g., institutional economics, sociology, behaviorism, psychoanalysis) in terms of which the legal system can be understood much better than by means of ordinary legal language. This second strand of legal realism is much more in the spirit of my sense of scientific realism, in that these theorists realized that it is not sufficient, for purposes of legal reform, to say simply (as Holmes seems to) that laws are made by humans not gods. In addition, one must endeavor to show that legal language itself distorts the understanding that insiders have of how the system works, and hence blinds them to various sorts of social injustices that are committed. For example, most of these legal realists believed that the best explanation of particular judicial decisions would invoke categories (as from Marxist class analysis) that could also be used to explain other social phenomena. In other words, in the master language, legal activity would not appear to be governed by regularities that are relatively autonomous from other aspects of social life. See, e.g., J. FRANk, LAw AND THE MODERN MIND (1930); K. Llewellyn, The Bramble Bush (1951); Bingham, What Is the Law?, 11 Mich. L. REv. 109 (1912); Pound, The Scope and Purpose of Sociological Jurisprudence, 24 HaRv. L. REv. 591 (1911).

20. See, e.g., R. RORTY, supra note 12 , at 306-11. 
wrong; that is, they want to make sense of what may be called the "anomalousness" of error. Antirealists, on the other hand, are concerned with understanding what people do as a result of having this feeling that something has gone wrong; that is, antirealists want to make sense of how particular errors, or anomalies, are defined. One consequence of this difference in emphasis is that realists are often caught up short by the fact that our confrontations with a supposedly naked reality have been resolved in so many different ways, each suited to the parties on hand; hence, the focus of legal theorists on the indeterminacy of decisionmaking. On the other hand, antirealists tend to be embarassed by an even more basic fact, namely, that people have little control over when or where their conflicts in perspective arise. I take this last point-antirealism's difficulties in accounting for the unexpected and unintended character of error-to be decisive in favor of realism.

Admittedly, much of the mutual embarassment here is an artifact of typically philosophical exaggeration. This is not to say, however, that the caricature has been without influence, both among social scientists and legal theorists. ${ }^{21}$ In any case, such a caricature makes it difficult for either realists or antirealists to give an adequate account of our fallible nature. The first step out of this difficulty is to recognize why mainstream social scientists do not seem to suffer from it. Our clue lies in the relativism that social scientists ordinarily presuppose-in the face of logical incoherence, if philosophers were to be believed. But, as we shall then see, vindicating relativism does not quite get us far enough to a robust treatment of our cognitive fallibility.

21. An instructive way of characterizing the nature of this exaggeration is in terms of the degree of reflexivity that the two sides exhibit about their own positions. In other words, to what extent does the realist or antirealist attempt to account for her own behavior in terms of her own position? Philosophers who are realists tend to be less reflexive about their positions than realists in other disciplines, while philosophical antirealists tend to be more reflexive than their counterparts in the other disciplines. For their part, philosophers committed to scientific realism usually have the natural sciences in mind and presume that the relevant sense in which reality is "independent" is with respect to all human activity, not merely human opinion. Thus, philosophical realists tend not to apply their positions to themselves, and in fact often make a point of arguing that there is no "fact of the matter" about concepts that are crucial for understanding the human condition. In fact, this was W.V.O. Quine's point in proposing the "indeterminacy thesis of translation," perhaps the most widely debated thesis in contemporary analytic philosophy of language. See P. Roth, MEANing AND METHOD IN the Social Sciences: A Case for Methodological Pluralism 130-51 (1987).

Conversely, philosophical anturealists are all too willing to take the reflexive turn, even to the point of rendering the past as open to human construction as is the future. Relevant in this regard is $M$. OAKESHOTT, EXPERIENCE AND ITS MODES (1933). Inspired by a strict reading of the phenomenological literature, some ethnomethodologists and legal theorists (including Singer and others who read Roberto Unger very literally) have gone so far as to argue that reality is created anew from moment to moment. Often these philosophical antirealists conclude that severe forms of mental illness, such as schizophrenia, consist simply of a heightened awareness of the inherently episodic nature of reality. It follows that attempts to "cure" mental illness are tantamount to suppressing our most natural encounter with the world. For more on this antipsychiatric orientation to the mind, see M. POLLNER, MUNdane Reason (1986); Critical Psychiatry: The Polmtics of Mental Health (D. Ingleby ed. 1980). One can certainly see the Cartesian Anxiety as the opening move down a slippery slope to this conclusion. 
The motivation for introducing relativism into anthropology in the late nineteenth century has been obscured by philosophers and their emulators in the humanities and the social sciences, who have been guilty of conflating antirealism with relativism and then collapsing the two into a solipsistic form of subjectivism. To illustrate these multiple conflations, take something as basic as the Protagorean motto of relativism: "Man is the measure of all things." Philosophers who invoke this motto nowadays take "man" as referring to any individual thinker, when in fact it originally referred to the average citizen of a given community, which would have made the sophist's words quite acceptable to the likes of Aristotle. ${ }^{22}$

Indeed, relativism originated as a species of realism designed to rectify obvious errors that were increasingly being committed by anthropologists theoretically committed to a unilinear conception of human evolution. In particular, too many of the practices of alien cultures were turning out to be rationally deficient, which only enhanced the mystery of how these cultures managed to survive as well as they did without feeling any need to "develop." The nascent relativist response was to argue that the evolutionists had misunderstood the point of these native practices, especially the function they served in maintaining the culture. Both sides of the ensuing dispute took the bone of contention to be over a matter of objective fact: Do alien practices routinely aspire, but fail, to express the norms exemplified in modern Western practices? Or rather, do these practices express some more locally appropriate norms?23 In addressing these questions,

22. The history of the usage of "relativism" is recounted in P. ROSENTHAL, Words and VALues: SOME Leading Words and Where They Lead Us 115-76 (1984). An often-cited recent philosophy article that collapses Protagorean relativism into solipsistic subjectivism is Swoyer, True For, in Relativism: Cognitive and Moral 84-108 (M. Krausz \& J. Meiland eds. 1982). Not surprisingly, Singer does the same. See Singer, supra note 2 , at 29 n.92. What Protagoras meant by "man" (anthropos) is discussed in W. GuThrie, A History of GreEx Philosophy: The FIFTH Century Enlightenment 188-92 (1969). Perhaps the first modern thinker to recognize that both Protagoras and Aristotle were proposing conceptions of socially embodied reason in opposition to Plato was Johann Georg Hamann, who played the sophist to Kant's Plato after Critique of PURE Reason was published. See F. Beiser, The Fate of Reason: German Philosophy from Kant TO FichTE 16-43 (1987).

23. In the terms used above, supra note 21 , mainstream practitioners of the social sciences tend to turn the tables on reflexivity, being reflexively realist or unreflexively antirealist. In fact, a simple example will show that these two positions really capture two aspects of a common position.

Imagine asking one of these unreflexive antirealists to define the truth. Clearly, he will refer to the results of the most reliable verification procedures available, probably in the natural sciences. Then ask him what happens when the procedures or their reliability change. He will readily say that the truth changes as well. But now ask whether those scientific procedures are themselves nothing but the results of the verification procedures that the antirealist himself uses for studying them. The antirealist will undoubtedly pause before answering, since a second positive response would imply that as his own methods for studying science change, the science under study also changes, and therefore the truth changes. In that case, the outcome of a particle physics experiment several years back would hang on the most recent resolution of methodological disputes in the historiography of science! Most historians of science would want to resist this conclusion, thereby refusing to apply their antirealism reflexively. At the same time, the historians continue to admit that the physics experiment did not have a particular outcome, until it was constituted by the verification procedures of the local physics community. But once that outcome had been constituted, it became a fact-on all fours with any other natural fact-which has since had real world consequences about which historians, including the one 
much ink was spilled on the proper way of identifying the norms governing a society-and much of that ink eventually spilled into so-called positivist theories of the law, especially through Hans Kelsen's inquiries into the Grundnorm of a legal system and Hart's search for the ultimate rule of recognition. ${ }^{24}$

But, as I suggested earlier, relativism does not provide us with an adequate account of human fallibility. For while relativism clearly highlights the liabilities of the social scientist, the natives are still presumed to have authoritative access to the norms governing their society. To fully realize the critical potential of scientific realism, as exemplified in Marxism, the possibility for error must extend to the natives themselves. There is a simple way of making this point, which will prepare us to delve into Singer and Stick more deeply.

In light of the previous discussion, we might charitably interpret both Singer and Stick as relativists of different stripes. They differ, of course, with regard to the legitimating authority in question Singer turns to the judge's personal deliberations, which puts him closer to the philosophical stereotype of the relativist than Stick, who defers instead to the consent of the community and thereby approximates the anthropologist's sense of relativism. However, neither takes seriously the possibility that the relevant insider(s) could issue erroneous legal judgments most of the time. Three examples of such errors, to be discussed in greater detail below, include: (a) a judge's failure to anticipate that subsequent interpreters of his decision would attribute to him a viewpoint that he did not intend; (b) the ability of a legislative body to agree on the wording of laws without agreeing on their meaning or intended range of application; (c) the inability of both judges and legislators to calculate the net effect of their legal actions on society, even if those actions were interpreted as intended. It is with these three sorts of examples in mind that the legal theorist influenced by scientific realism would attempt to deconstruct the recent talk about indeterminacy and community.

\section{Singer versus Stick on Indeterminacy: A Gloser Look at THE CROSSFIRE}

Singer and Stick frame their discussion of indeterminacy in terms of the problematic status of theory in the law. At first glance, Singer's view of the situation seems quite simple:

under discussion, have made claims that are, in some univocally realist sense, either true or false, regardless of whose methodology happens to be in favor. Thus, our historian is also reflexively realist. An interesting dramatization of this issue among recent sociologists of science may be found in $M$. Mulkay, The WORd and the World (1985).

24. H.L.A. HART, supra note 9, at 97-106. The similarity between discovering the norms of an alien culture and that of a legal system is made explicit in M. GoldiNG, supra note 19. 
Legal theory is far more indeterminate and open-ended than its adherents claim, and it expresses controversial political and moral commitments rather than universal principles grounded in human rationality.

Theory expresses our values; it does not create or determine them. Theory is useful to the extent that it articulates what we value. We "draw a line" between competing principles and then create a theory to describe where we chose to place the line. But the theory does not itself reconcile those values or tell us where to draw the line. It cannot because it is something we made up to express those values and the "line" between them. To think otherwise is to reify theory, to remove it from human control and to pretend that it is telling us what to do. But it cannot tell us what to do-we created it. I am not suggesting that theory is meaningless. As $I$ argued earlier, it can structure our thinking in a way that limits our perception of the available alternatives. But it is important to remember that this is because we structured it to do this. We told ourselves what to do. ${ }^{25}$

But Stick suspects that Singer's position may involve more than meets the eye:

More troubling, [Singer's] discussion of theory and values assumes that values can affect theory, but that theory does not affect values. In other words, reasons are always adopted after value choice and never influence value choice. Singer at times seems to say that nothing can be said about personal choice; theorists can point out the fact of choice but thereafter must stand mute. . . .

There is an odd convergence between Singer's account of values and that of free market theorists. Both consider the formation of values beyond rational discussion. Market theories of legislation, the administrative process, and the common law attempt to take the discussion of values entirely out of public life. In the market, all that matters is the fact of one's choice and not the reasons for it. I would think both radicals and liberals would seek to reopen public life to the full discussion of values, and not to aid in the reduction of public discourse to claims of self-assertion. ${ }^{28}$

One thing is clear: "Theory" has fallen on hard times in the law. Was it so long ago that philosophers of science were celebrating the theory-laden character of observation and Western Marxists were paying theory the ultimate compliment of calling it a form of "revolutionary practice"? ${ }^{27}$ But now that legal theory has decided to model itself on literary theory, Singer has joined Stanley Fish's band of nihilists, proclaiming, "Theory

25. Singer, supra note 2 , at 60 .

26. Stick, supra note 2 , at 391 \& n.255.

27. For treatments of this question, in both philosophy of science and Marxism, see R. BHASKAR, Scientific Realism and Human Emancipation (1987); A. Callinicos, Marxism aind PhilosOPHY (1983). 
has no consequences!"28 Throughout his footnotes, Stick detects a sense of deja $v u$ in Singer's turn against theory, which is no surprise, since the last great wave of anti-theory was logical positivism, the common foe of the theory-laden philosophers of science and the Western Marxists. ${ }^{29}$ And as with the last wave, the one on which Singer rides pastes over trenchant ambiguities with punchy slogans. After all, what exactly does it mean for theory to have no consequences? Here are three rather different answers:

(a) Theory cannot, by definition, have any consequences.

(b) Theory does not, in actual fact, have any consequences.

(c) Theory ought not, as a matter of principle, have any consequences.

Stick seems to realize that Singer is on progressively shakier ground, as he slides from (a) to (b) to (c). At least, Stick sees that (a) is the most persuasive reading of Fish's slogan, namely, as the thesis that formulating a theory and specifying its proper application are logically distinct activities. ${ }^{30}$ Even if persuasive, (a) is hardly cause for alarm, since it is just an abstract way of explaining the division of legal labor between legislators and judges: Laws can't be drafted in anticipation of all future cases, and cases don't come packaged with instructions for legal subsumption. Admittedly, analytic philosophers, especially followers of the later Wittgenstein,

28. Fish makes his case in Fish, Consequences, in Against Theory: Lrterary Studies and THE New PRAGMatism 106-31 (W. Mitchell ed. 1985); see also Fish, Dennis Marinez and the Uses of Theory, 96 YALE L.J. 1773 (1987).

In Dennis Martinez, supra, Fish argues that being able to articulate what one is supposed to do in a baseball game (here, that Dennis Martinez, a pitcher, should throw strikes) is neither sufficient nor necessary to complete the task. One must also have an intuitive understanding of what to do when playing the game, and having that intuitive understanding makes it unnecessary for one to have an articulated theory of how to play the game. The theory of baseball, in other words, is irrelevant to the practice of baseball.

Fish diverges from Singer in that he directly addresses the question of how we are to make decisions if we are not to rely on theory. He argues that we make our decisions on the basis of an "enriched notion of practice," which lets us intuitively pick out those aspects of a situation which we regard as most important. (For a comparable view cast in terms of how judges make decisions, see Kennedy, Freedom and Constraint in Adjudication: A Critical Phenomenology, $36 \mathrm{~J}$. Legal Educ. 518 (1986).) In essence, Fish uses practice as a substitute for what theorists have traditionally meant theory to do-highlight some aspects of situations as important, others as irrelevant; select options; frame alternatives; provide the means for evaluating the desirability of the results of our decisions. It seems that he must answer all the questions that he posed to those who argue for the primacy of theory.

Fish, however, tries to deflect attention from this fact. He does this by misconstruing what it means to follow a theory. For instance, he says that a pitcher in a baseball game who did not try to throw strikes would not be recognized as playing the game at all. This conflates what it means to play the game seriously and competently with what it means to be doing something that is recognizable as playing the game at all. The former situation is governed by regulative rules, the latter by constitutive rules. Fish's effort-which largely repeats John Rawls' original effort (baseball example and all) in Rawls, Two Concepts of Rules 64 PHIL. REv. 3 (1955)-is nonetheless an improvement on Singer's work, which ignores this question.

29. Logical positivism was "anti-theory" in holding that a scientific theory was "cognitively significant" solely in virtue of-and hence was reducible to-its logical structure and its observable consequences. See Logical Positrivism (A. Ayer ed. 1959).

30. See Stick, supra note 2, at 361-67. (A) is the most persuasive reading of Fish's slogan, insofar as his paradigm case of a "theory" is Chomsky's generative grammar, which Fish faults for being insensitive to the context-bound nature of linguistic usage. See Fish, Consequences, supra note 28, at 108-11. 
have made much of (a)'s implications for language's grip on the world, to wit, that it is "indeterminate."31

However, our interlocutors seem to be of two minds about the source of indeterminacy in the legal system. ${ }^{32}$ On the one hand, there is the sort that arises from the judge (or legal community) being unable to specify all the premises which together determine that a case be decided in a certain way. This is the sense of indeterminacy which is sometimes characterized as the "tacit dimension" of legal reasoning. ${ }^{33}$ On the other hand, indeterminacy may arise from the judge (or legal community) being unable to give any principled reasons why a particular case ought to be subsumed under one rule rather than another. This is the sort of indeterminacy that gives legal rules their supposed "open texture," which makes them usable in cases that had not been anticipated by the original legislators, and perhaps even contrary to the legislators' intentions. ${ }^{34}$ I suspect that these two senses of indeterminacy are confused because they are both ultimately grounded in our general inability to monitor and control language use in society at large, a fact that is most easily recognized from a realist perspective. ${ }^{35}$

31. The post-positivist concern with indeterminacy is epitomized in L. Wrttgenstein, PhiloSOPHICAL INVESTIGATIONS (1958). To see the hidden influence of this concern in the philosophy of law, consider the cases of Hans Kelsen (who attended the meetings of the Vienna Circle) and Herbert Hart (who was a student of Wittgenstein).

32. A curious feature of the Singer-Stick debate is that our two interlocutors treat indeterminacy as a univocal phenomenon with several "sources" rather than as a collection of rather disparate (at least two distinct types of) phenomena. See Stick, supra note 2, at 352-69.

33. The expression "tacit dimension" originates with M. Polanyı, Personal Knowledge (1957), which argues that most of what scientists learn in their training involves an inarticulate sense of "know-how" similar to that required to gain mastery of a craft. It is an intrinsically practical, not theoretical (or propositional) form of reasoning. Nevertheless, this has not stopped artificial intelligence researchers from trying to model scientific reasoning "algorithmically," i.e., as a set of rules sufficient for determining some outcome. The same applies to legal reasoning. An especially good example is A. Gardner, An Artificial Intelligence Approach to Legal Reasoning 33-66 (1987). Gardner argues that legal reasoning seems indeterminate only because legal rules are alone insufficient for determining legal decisions. In addition, there are extra-legal value premises, which vary from judge to judge, and hence make legal decisionmaking seem indeterminate. However, for each decision, Gardner believes that one could supply the missing value premises. A general critique of this sort of attempt to minimize the import of the tacit dimension is H. Dreyfus \& S. Dreyfus, Mind over Machine (1986).

34. The expression "open texture," while associated with Wittgenstein's later writings on the learning and extension of concepts, was in fact coined by one of the original Vienna Circle positivists, Friedrich Waismann. See Waismann, Verifiability, in LANGuage and Logic (A. Flew ed. 1951).

35. The antirealist impulse is revealed in the tendency (by no means confined to Singer and Stick) to presume that the tacit dimension is indeterminate. Yet, what is neither said by nor readily accessible to a reasoner may still have a status just as determinate as those features of his reasoning to which the reasoner has ready access. At least the realist can make this claim, since for her the only difference between the articulated and the silent is that the former is perceived and the latter is not. But only the antirealist ties reality to perceivability and accessibility. Thus, even if H. DREyfuS \& S. Dreyfus, supra note 33 , is correct in maintaining that fully articulating the tacit dimension would require infinitely many propositions, those could be infinitely many determinate propositions, whose trenchant inarticulateness would rest merely on the fact that we are not able to articulate indefinitely: again, a case of cognitive fallibility.

As for the "open texture" sense of indeterminacy, its trenchant character may be seen in the repeated failures of grammarians and other linguistic purists to fix the meanings of words. Wittgenstein has since taught us to rationalize the inevitability of semantic drift by celebrating the flexibility of 
Even more typical of the recent debates in legal theory is the tendency for interlocutors to misfire between the (b) and (c) senses of "theory has no consequences." In particular, Singer asserts (c) and Stick then spends most of his ammunition denying (b). Singer's proposed escape from mere nihilism is an "expressivist" theory of law, which starts from the Rousseavian premise that theory's burdens should weigh more lightly on our minds once we realize that they are self-imposed. ${ }^{36}$ Such assurances offer small comfort, however, unless Singer specifies whether he would have legal theorists merely reinterpret what they normally do (i.e., as an "expressive" rather than a "mechanical" process), or whether he would actually have theorists liberate their reasoning in some yet-to-be-disclosed manner. Stick is bewildered by all this, but he seems to think that Singer's musings on how legal theorists ought to think (about how they think) can be answered by showing that legal theorizing has in fact issued in a convergent set of political options, which have been most clearly articulated by contemporary liberalism. ${ }^{37}$

The problem with Stick trying to answer Singer in this fashion is that even if he were to succeed in demonstrating that American legal theory has tended toward liberal political consequences, Stick would still be faced with the task of demonstrating that legal theory as such -and not merely something contingently associated with it (such as the class backgrounds of key theorists) - has actually been responsible for the liberal consequences. Pending this second demonstration, Singer, in fine CLS form, can continue to explain away Stick's appeal to a concrete liberal consensus as simply indicating that many different interests have been able to travel under the mantle of liberalism. Indeed, in Singer's hands, this would be an argument for condemning talk of "liberal consensus" as a deceptive ideological practice.

So far, it looks as though Singer and Stick have been shooting past each other. But this is not to say that they have not missed some key targets as well. In particular, they miss two targets, which, if confronted squarely, would force them to recognize the sense of cognitive limitations that is most apparent from a realist standpoint.

To get the first target into view, consider that while our two interlocutors have much to say about whether there is a rational pattern in the application of legal theory to specific cases, neither says much about whether there is a rational pattern in the specific cases which give rise to the application of legal theory. It is one thing to argue that judges decide

linguistic rules in capturing new situations. Indeed, the ease with which we nowadays accept Wittgenstein's story moves us dangerously close to the belief that language was designed to be ever-creative and ever-adaptable. That this is little more than a "just-so" story becomes clear upon recalling that our limited capacity to monitor and coordinate the utterances of dispersed speakers leaves us no choice but to make do with language perpetually adrift.

36. Singer, supra note 2 , at 59-70.

37. Stick, supra note 2, at 383-401. 
cases in a rational fashion, but quite another to argue that the cases themselves arise in a fashion conducive to rational decisionmaking. For example, even if we granted Stick's point that, under the circumstances of a given case, a judge generally makes the most rational decision he can, an enemy of judicial rationality could always respond that the legal system has so little control over the "circumstances" in which cases arise-perhaps because they depend so heavily on changes in the political climate-that a judge is repeatedly forced to trade off high-minded principles of rationality against short term political expedients. This, in turn, serves to attenuate Stick's concept of judicial rationality beyond all recognition-but hardly in a way that Singer could approve. After all, the judicial irrationalist's argument plays, not to the expressive strength, but to the cognitive weakness of the judge. ${ }^{38}$ Singer's image of theorizing as "drawing a line" is useful here. For while we may decide where to draw the line between competing principles, we do not decide when such a line needs to be drawn, which suggests that we also have little control over whether the line is likely to stay exactly where we draw it.

The second target can also be seen by paying close attention to Singer's text, especially to his equivocal use of the first-person plural. The reader immediately knows that something has gone awry when a community is able to take comfort in the sort of solipsism implied by "We told ourselves what to do." Singer seems to be appealing to a bogus social epistemology, whereby all members of the community move as one mind, hence permitting an easy equation of "we" and "ourselves." Stick picks up on some of this in his bafflement over Singer's propensity to treat collective decisionmaking as simply individual decisionmaking writ large: "we" as a generalized "me."

Ultimately, I suspect that Singer is given to this absurd rhetoric because he confuses two senses of "membership." On the one hand, I may be a "member" of a group by being one of a set of people with similar attributes; on the other hand, I may be a "member" by having attributes complementary to the ones had by the people with whom I constitute the

38. The judicial irrationalist in the example is actually espousing a form of "bounded rationality," which is the only sort of rationality possible, given severe cognitive constraints. This point was first made in the late 1940 s when Herbert Simon criticized the utility-maximizer model as being too idealized a picture of real agents to be of much use in predicting the complicated patterns of economic behavior found in modern society. For an excellent review of research in this area, see March, Bounded Rationality, Ambiguity, and the Engineering of Choice, in RATronal CHolce 142 (J. Elster ed. 1986). Since 1960, Simon has helped steer artificial intelligence research away from developing "the perfect computer" to modeling the imperfect computations of cost-and-corner-cutting reasoners like ourselves. See H. Simon, The Sciences of the Artificial (2d ed. 1981).

Simon has a distinctive slant on our cognitive liabilities; for example, he would argue that humans are very fallible because they cannot reproduce by their own means (i.e., either "in the head" or "on paper") the complexity that exists outside their means. Social constructions thus come to take a life of their own because our means of monitoring and controlling their use are fundamentally unsystematic. Id. 
group (e.g., a quarterback on a football team). ${ }^{30}$ Since Singer basically treats the second sense as little more than the first, he fails to see that, even granting consistent enforcement of the law, any piece of legislation or adjudication will have a wide range of effects on the members of society, relative to their social position, most of which cannot be anticipated and would not have been intended. ${ }^{40}$ For example, affirmative action legislation may serve to catalyze a heretofore docile segment of the white middle class to rethink their notions of social justice, leading to the ouster of the original legislators. To return, once again, to Singer's image, members of the society who were motivated to draw a line between competing principles do not necessarily turn out to to be the ones who benefit from the line having been drawn.

\section{REALISM AND the Resolution OF INDETERMinacy}

As we uncover the muddles in which Singer and Stick are mired, the reader should ask whether the "indeterminacy" is supposed to lie in the essential incompleteness of language (or law) itself as a representation of the world or merely in our own uncertainty about how the representational process works. The antirealist characteristically holds reality accountable for failures that the realist would blame only on our limited cognitive grasp.

A good place to begin our inquiry is with the quote from CLS historian Robert Gordon on which Singer bases his discussion of indeterminacy:

[By "indeterminacy," the CLS scholars] don't mean-although sometimes they sound as if they do-that there are never any predictable causal relations between legal forms and anything else. . . . [T] here are plenty of short- and medium-run stable regularities in social life, including regularities in the interpretation and application, in given contexts, of legal rules. Lawyers, in fact, are constantly making predictions for their clients on the basis of these regularities. The Critical claim of indeterminacy is simply that none of these regularities are necessary consequences of the adoption of a given regime of rules. The rule-system could also have generated a different set of stabilizing conventions leading to exactly the opposite re-

39. The distinction in membership that Singer fails to see is one that late nineteenth century sociologists commonly used to differentiate societies before and after the division of labor had set in. Before members of a society acquired specialized tasks, they were joined together by "mechanical solidarity," which is to say, by their similarity or functional interchangeability. Once specialization had emerged, the social bond was constructed out of "organic solidarity," which implied that the members were functionally interdependent. A famous account of this transition is E. DURKHEIM, THE Division OF LABOR IN SocieTY (1957).

40. For this reason, Friedrich von Hayek and other "classical liberals" have argued that consistent enforcement is the only sense of justice that the law can administer without intruding on personal freedom. Moreover, the fact that the law affects different social groups differently has the added benefit of continually renovating how those groups relate to each other. See F. HAYEK, ThE CoNSTITUTION OF LIBERTY (1960). 
sults and may, upon a shift in the direction of political winds, switch to those opposing conventions at any time. ${ }^{11}$

Gordon's quotation is interesting because, for all its apparent lucidity, it continues to leave in doubt the exact role that legal rules play, or could play, in determining the outcomes of particular cases. Can lawyers reliably use legal rules, in conjunction with other socio-political indicators, to determine the outcome of a case before the judge actually makes his decision? $\mathrm{Or}$ is it rather that lawyers can reliably determine the legal rules to which the judge will appeal in justifying his decision, once he has already decided the outcome of the case? The potential indeterminacy of legal rules implied in these two questions is quite different. In the first question, legal rules are "indeterminate" in the sense of telling an incomplete story of how the judicial decisionmaking process works, since sociopolitical matters also enter into a judge's reasoning. In the second question, however, the "indeterminacy" of legal rules stems from their playing no real causal role in the judge's reasoning, since the rules serve merely to rationalize the decision, after the fact, in a legally acceptable manner.

The distinction between these two senses of indeterminacy is most apparent to someone viewing the legal system from the outside because the outsider would have a clear sense of the conceptual difference between what best explains a judge's decision and her own way of accounting for it. While the judge's conscious deliberations may reflect the true movement of her reasoning, there is no a priori reason to think that it does. Instead, a better account may require appealing to categories-perhaps Marxist or psychoanalytic ones-cognitively unavailable to the judge and, in any case, irrelevant to her duties (in the same way that complex linguistic rules are unavailable to the average speaker). After all, the judge's authority rests not on her own impeccable powers of self-knowledge, but on the network of legal relations in which she plays a major role. ${ }^{42}$ Now

41. Gordon, supra note 6, at 125, quoted in Singer, supra note 2, at 20 n.55.

42. Experimental psychologists have repeatedly shown that "expert judgment" is often not much better than the judgments of lay people, and that when the experts get things right it is not because they have systematically applied their professional training. As a result of these findings, a consensus is emerging that expert reasoning is more "intuitive" than "analytical," a suspicious distinction which on close inspection simply reifies the fact that experts reason in a manner sufficiently irregular to elude everyone's understanding. What this means, of course, is that most faulty judgments probably go undetected in the normal course of things. This tale of cognitive woe is told for virtually every area of expertise (including the law) in Judgment and Decision Making (H. Arkes \& K. Hammond eds. 1986).

These liabilities may eventually cancel each other out and do some unintended good, but at the very least they cause an imperceptible drift in the grip that our social constructions have on the world, hence giving them a life of their own. For a try at giving these dismal findings a Panglossian twist see Stich, Could Man Be an Irrational Animal?, in NATURALIzING EPISTEMology 249-67 (H. Kornblith ed. 1985). Based on the experiments, Stich must answer yes, but he then speculates that this is because "rationality" is really not a single cognitive competence, but rather diverse skills which require explicit training in specific fields. Since we cannot reasonably be expected to master every field, we normally must defer to the cognitive authority of others, which in turn fosters a cooperative spirit. Stich's tale would be more convincing if experts performed somewhat better on these experiments than 
contrast this position with Singer's, which discusses judicial decisionmaking as if he himself were the judge:

The same theories could be used to justify very different sorts of institutions and very different rules. This does not mean, however, that outcomes in our legal system are completely unpredictable or that the choices made by judges are arbitrary in the sense that they are unconsidered. Considered choices can be described and even predicted to some extent because they are conditioned by legal culture, conventions, "common sense," and politics. Custom, rather than reason, narrows the choices and suggests the result. ${ }^{43}$

The expression that gives away Singer's confusion of Gordon's position is "considered choices." Singer supposes that no matter how incomplete a picture of judicial decisionmaking legal rules may give, they must play some causal role in the final outcome because those rules figure in the judge's explicit "considerations." Since Singer presumes that the judge is an epistemic authority on her own reasoning process, he cannot entertain the second sense of "indeterminacy" that was culled from Gordon. Consequently, he is unable to deal with, for example, the Marxist hypothesis-treated by Gordon himself (to his credit) - that legal rules are mere ideological epiphenomena, ways in which agents in the social system deceive themselves and others about how the system works.

Stick hardly helps matters here, since he explicitly denies that the legal system could ever be engulfed in false consciousness, where all reasons turn out to be nothing but rationalizations. Like Singer, he takes the only legitimate standpoint from which to evaluate the law to be the "inside," his only difference being that he would make the judge accountable, not merely to her own conscience, but also "to what practicing lawyers themselves say about the standards of rationality."

Stick is confident that error will continue to be-as it has been in the past-corrected before reaching the systemic proportions feared by Marxists. However, it is by no means clear that Stick has a firm grasp on the sort of Marxist ideology critique which Gordon and the more systematic members of CLS periodically practice-especially in light of his reliance on the following sort of argument: "But a belief that all of our standards of rational argument are mere rationalizations is self-refuting and unintelligible on its own terms." ${ }^{\text {"45 }}$ Stick himself undermines this argument in the

they in fact do. Another, and somewhat more acceptable, reading of the psychological data is provided in D. FAUST, The Limits of SCIENTIFIC ReAsoning (1985). Faust argues that our trenchant cognitive liabilities point toward a scientific ethic of mutual criticism along the lines suggested by Karl Popper.

43. Singer, supra note 2, at 24-25.

44. Stick, supra note 2, at 353; $c$. Holmes, supra note 19.

45. Stick, supra note 2 , at 358 n.108. The argument is taken from H. PUtnam, Reason, TRUTH, AND HistoRy 155-63 (1981). 
last four words, since only someone attempting a total critique from within the legal system would be rendered unintelligible. For in that case, the critic would be in the paradoxical position of using the system's own terms to convey their systematically misleading character. But, of course, the Marxist's analytic categories are not those of the law; rather, they constitute a "metalanguage" in terms of which the distortions of legal reasoning can be coherently and systematically uncovered. At this point, we would do well to examine Gordon's work more closely to see how the potential for total critique of the law can be realized-even if Gordon himself falls somewhat short.

Gordon's basic strategy is to deconstruct the "lawlike" qualities of the

Marxism has generally not fared well in the recent legal theory debates, either in the hands of a liberal like Stick or a CLS partisan such as James Boyle (see supra note 13, at 721-36). Not surprisingly, both read the Marxist as an antirealist for whom scientific progress would entail reducing legal categories to socio-political ones, especially categories identifying the dominant class interests in a society. On such a view, legal terms do refer to regularly occurring social events, ones whose regularity is controlled by these interests. This antirealist misreading of Marxism, to which Boyle succumbs, better fits certain vulgar forms of legal realism. The British legal theorist Hugh Collins has dubbed the misreading "the fetishism of law." See H. Collins, Marxism and Law (1984). Unfortunately, as Collins notes in painful detail, Marx's avowed followers have been among the main fetishists. What this fetishism misses is Marx's own characteristic realism, which stresses our inability to prevent social constructions from attaining lives of their own. Indeed, this is the most important sense (Hegel's originally) in which alienation occurs at the societal level. Thus, the law is neither part of the social order's causal infrastructure nor the mere instrument of the dominant class, which are the only two options available on the antirealist misreading. Rather, the Marxist realist regards the law as an alienated and false self-understanding of a society's workings, to which all classes appeal-at least prior to their Marxist awakening-in order to legitimate their activities. In short, law is the ideology that is common to all interests in a society. For more on Marxist realism, see R. BHASKAR, supra note 27; A. Callinicos, supra note 27.

Roberto Unger's reading of the failure of Marxism has colored what even CLS theorists have taken to be Marx's significance. See supra note 4; see also infra note 52 . Unger applauds Marx, especially Marx's early writings, for being sensitive to the contexts in which alienation is personally experienced and the extent to which those contexts are the product of people imposing their wills on others who often simply do not resist because they take their fate to be much more determined than it really is. These are the sources of Marx's radical message. Marx went wrong, according to Unger, when he turned his attention from particular contexts to large scale structures, which more easily promote the illusion of social stability and indeed led his "orthodox" followers to recommend political quiescence until the relevant structures had reached an appropriate point in their development. Thus, whercas Marxists have tended to think that a comprehensive social science was the key to setting the agenda for revolutionary practice, Unger argues that this has in fact had an inhibitory effect. The key, rather, lies in seeing the large scale social structures as illusory surfaces for the supposedly real indeterminacy of human action that occurs at the local level in the course of reproducing these structures. Unger's attitudes toward Marx come out clearest in R. UNGer, Social THEORY, supra note 3, at 96-130, 230-35.

Unger's view of Marx is very much in evidence in Singer's misreading of the famous opening of the Eighteenth Brumaire of Louis Napoleon:

"[People] make their own history," Marx tells us, "but they do not make it just as they

please; they do not make it under circumstances chosen by themselves, but under circumstances

directly found, given and transmitted from the past." We should be comfortable viewing both rationality and social life as historically and culturally situated. Viewing legal theory in this way will allow us to exorcise the wrongful expectation that some politically neutral, ahistorical method can generate answers to questions about what the legal rules should be.

Singer, supra note 2, at 63 . Singer makes it seem as though Marx's point is that the rationality embodied in social history is limited to the interests and issues recognized by decisionmakers at the moment, when in fact Marx is making the quite opposite Hegelian (and realist) point that people are the unwitting instruments of history, the recipients of the unintended and unanticipated consequences of past decisions. 
law by descending into ever finer levels of microstructural analysis. Thus, from the easily falsified idea that the law governs all uniformly, he proceeds to show that the law does not have uniform responses to specific social needs, nor does it even weigh for or against particular interest groups on a regular basis. The most curious feature of this interesting approach is that it leaves Gordon fairly optimistic about the feasibility of individual empowerment along the lines associated with Roberto Unger. ${ }^{46}$ Gordon's optimism, however, seems to rest on two interconnected but controversial assumptions.

First, Gordon assumes that if the legal deconstructionist has traversed the various levels of social structure in which the law operates, only to find indeterminacy at each level, then he has reached the end of his inquiry. Second, Gordon assumes that awareness of this fact should encourage disadvantaged individuals and interest groups to stake their claims ever more vigorously, since their voices could indeed make a difference in the outcomes of particular cases. The problem with Gordon's making these two assumptions is that they reflect an antirealist bias, whereby the inquirer's inability to transcend a certain stage in his analysis is taken as evidence of the indeterminate or diverse character of the object of inquiry. However, at the level of total critique, where Stick would dare not venture, a systematic account of legal phenomena may be possible, though it may also involve showing that the law is much more continuous with the rest of society than legal language would itself suggest. Nevertheless, such a conclusion would not be inhospitable to the outsider perspective of the realist. ${ }^{47}$

46. R. Unger, The Critical Legal Studies Movement 52-56 (1986). A good case study is Note, Petitioning and the Empowerment Theory of Practice, 96 YALE L.J. 569 (1987).

47. Here is a sketch of such a realist argument, consonant with Gordon's work and modeled on similar arguments made by realists in other branches of science:

(1) Taken on its own terms, the law constitutes a more or less coherent system of propositions, including generalizations about, e.g., the defeasibility conditions for applying legal concepts (Hart) and the sanctions that judges are obliged to apply when a law has been broken (Kelsen).

(2) However, legal entities such as "contract," "volition," and even "the rule of law" itself cannot be related to non-legal entities (e.g. types of social action) on a regular basis. Thus, depending on the context, the same law may be enforced under a variety of mutually incompatible social conditions.

(3) It may be tempting-if only to encourage people that political action can make a difference to what courts and legislatures decide-to conclude that the law is relatively autonomous from the rest of society and that, as a result, its workings cannot be fully determined by any set of socio-political regularities. Nevertheless, this observed indeterminacy may simply be the result of legal categories failing to refer to any regularly occurring events in society, the implication being that legal terms do not pick out any entities that play a causal role in the social order.

(4) This conclusion may seem less radical if we recall that the law (i.e., legal discourse) serves primarily a justificatory role, and only secondarily an explanatory one. In other words, legal generalizations normally occur in accounts of actions already committed (e.g., during a trial), where the point is to make sense of the particular case under study rather than to predict the appearance of subsequent cases of that kind.

(5) Finally, let us be clear as to what exactly has been "eliminated." No one is denying the occurrence of particular events in which laws and legal concepts are said to be "enforced," "broken," "enacted," "repealed," and so forth. Rather, what is being denied is that the existence of "laws" or thear occult "enforcement" would need to be posited in explaining those episodes, and hence in relia- 


\section{Unresolved Indeterminacy: Freedom as Ignorance in DisGUISE}

As the source of many of the leading ideas in the Singer-Stick debate, Roberto Unger is responsible for characterizing indeterminacy as something that can be made to work in our favor "if we want," to use one of Singer's favorite phrases. Unger takes the indeterminacy of legal rules as occasions for "self-empowerment," or asserting one's "destabilization rights." 48 Let us consider these ideas more closely. Unger argues that while the law tends to be applied in a manner that is systematically biased against certain classes, we need to keep in mind that these biases are ultimately nothing more than the aggregation of particular cases being resolved in particular ways. Consequently, each new case is an opportunity for either reproducing or destabilizing the bias. What Unger does not seem to notice is that the legal system is sufficiently independent of the wills of particular individuals-indeterminacy and all-that if a concerted and systematic effort is not made to destabilize the regnant biases on a

bly predicting similar subsequent episodes. This point is analogous to the one made by sociologists of religion, who do not normally deny the experience that the theist characterizes as a "belief in God," but only that theological categories figure in the best explanation of the theist's experience.

This argument is modeled on the steps by which certain hard-line realists in cognitive science eliminate the need to postulate the existence of such folk psychological entities as beliefs and desires in order to explain what they take to be purely neurobehavioral phenomena. For the arguments leading to these radical conclusions, see P. ChuRchland, Scientific Realism and the Plasticity of Mind (1979). The debate on this topic is recounted in S. STrch, From Folk Psychology to COGNITIVE SCIENCE (1983).

The reader should see the arguments in light of the remarks I made earlier about the second strand of legal realism (supra note 19), the ways in which a realist could reinterpret the apparent indeterminacy of concepts and terms (supra note 35), and the general scientific realist premise that scientific language (e.g., the Marxist's metalanguage or the standpoint of the outsiders) is significantly different from ordinary language in making an explicit effort to capture the ultimate regularities of nature, and not simply to make sense of an event in terms of a standing piece of common sense. Of course, antirealists have failed to see any such difference and have even tried to give Wittgensteinian accounts of scientific language. See, e.g., B. Barnes, T.S. Kuhn and Social Science (1982).

48. R. UNGER, supra note 46. Unger's prognosis is overly optimistic if it rests, as it seems to rest, on the assumption that people have more control of their situation when they are able to act on behalf of concrete self-expression than when they are forced to act in conformity with abstract expressions of legislative will. At first, the assumption appears quite reasonable, if only because we presumably have more intimate knowledge of ourselves than of the law, the construction of which we have given at most tacit consent to. Yet, here too, the experiments tell a tale of cognitive woe, for the selfinterestedness of one's reasoning is no guarantee that it will be especially well monitored or informed. Again, this is not to deny that people will try to maximize their own interests and perhaps even be more strongly driven toward that end than toward conformity with the law. All I deny is the likelihood of their success. On the inability of subjects to act consistently to satisfy their own self-defined interests (as expressed by incompetence at formulating expected utilities), see Tversky \& Kahneman, The Framing of Decisions and the Psychology of Choice, in Ratronal Choice, supra note 38, at 123-41. Regarding our self-predictive and self-explanatory liabilities, see R. NisBeTT \& L. Ross, Human Inference: Strategies and Shortcomings of Social Judgment (1983).

To dispel the thought that the law's indeterminacy makes it a willing instrument of special interests and systematic biases, the antirealist should conduct a long-term historical study which clearly separates the interests that motivated a particular piece of legislation or judicial decision from the interests that subsequently benefited from that legal action. If the law is anything like science, there will be remarkably little overlap in the two sets of interests. Indeed, given the likely shifts in the balance of power over time, it would not be surprising to see the motivators not benefiting, and perhaps even suffering, from their original actions. 
mass level, then the few isolated pockets of successful self-empowerment will appear as minor statistical aberrations. Here too we see a mismatching of perspectives, an attempt to treat from an insider's perspective a problem that is ideally seen from the outside (i.e., the reality of the legal system independent of one's own case). This aspect of Unger's thinking comes out most clearly in its influence on Singer's brief discussion of empowerment:

How then do we make value choices? The desperation with which people ask this question rests on the assumption that legal rules obtain whatever legitimacy they have by being chosen in a way that is essentially different. By now it should be clear that I do not think that there is a difference. And this revelation should not be experienced as leaving us helpless; rather, it should be experienced as empowering us. ${ }^{49}$

In what follows this passage, Singer continues hir upbeat message, observing, among other things, that our competence in making value choices is evidenced by the fact that we can live with those choices, and that our freedom to choose as we do is reflected in our ability to imagine alternative ways of weighting the relevant considerations, which would have led to the application of different legal rules. The inferential links suggested here between, on the one hand, competence and survival, and, on the other, freedom and contingency, are among the most epistemically fallacious and politically naive consequences to be drawn from focusing exclusively on the insider perspective.

Singer's alleged connection between freedom and contingency is quickly disposed of. My awareness of alternative possibilities may indeed establish that the world could have been other than it is, but my awareness says nothing about whether it was within my power to bring about one of those alternatives. For example, I can imagine a world in which I voted for Reagan in 1980 and for Lincoln in 1860, but clearly only the former was within my power to bring about. ${ }^{\text {so }}$

49. Singer, supra note 2 , at 62 .

50. This point is made in J. Searle, Minds, Brains, and Science 98 (1984).

In addition, it has become common for European social theorists (e.g., Anthony Giddens and Pierre Bourdieu) to observe that from a pre-theoretical, phenomenological standpoint, freedom and constraint feel exactly the same. What makes the difference is the background knowledge that the agent has. See J. Thompson, Studies in the Theory of Ideology 42-72, 148-72 (1984).

If this point seems counterintuitive, consider that the exercise of either freedom or constraint requires that one's experience be much more structured than the concept of indeterminacy would suggest. After all, indeterminacy implies that the world is indifferent to all possibilities, so that only chance makes the difference as to which one is actualized. Both freedom and constraint involve narrowing the possibilities down to a set of "options," the relative preference and feasibility of which can be ordered by the agent. Moreover, it is important that this set be finite, otherwise the problem will escape the agent's cognitive powers, which will either immobilize him entirely or force him preemptively to cut down what decision theorists call "the possibility space." If the preferred options are feasible, then the agent is relatively free; if not, then he is relatively constrained. Moreover, the level 
Singer's other fallacious inference, from survival to competence, is short-circuited by noting that, given our trenchant cognitive limitations, whatever permits us to survive from one decision to the next mustork by compensating for those limitations. After all, were we not acquainted with the experimental and historical evidence of our cognitive liabilities, we would be like Singer and hardly notice them. Consequently, strategies must have also evolved for converting our debits into assets. Two of these strategies, sour grapes and precommitment, have been studied in some detail by the Norwegian political scientist Jon Elster. ${ }^{51}$ The name "sour grapes" alludes to the fable by La Fontaine, in which a fox learns to live with its inability to reach the grapes at the top of a tree by persuading itself that the grapes were probably sour anyway. As we can see from this example alone, the strategy works to show that a seemingly suboptimal state of the world is not really so bad-and that any other possible world would probably be worse anyway. While sour grapes is clearly a species of rationalization, it should not be assumed that a belief influenced by sour grapes is necessarily false, for the grapes may well be sour. At the same time, though, the fox's hypothesis is clearly unfalsifiable, since it was uttered with the express purpose of not being tested. In other words, a presupposition of sour grapes is that the agent is sufficiently satisfied with the current state of the world so as not to have an interest in exploring the alternative that is debunked by his hypothesis.

Since sour grapes itself involves a warped understanding of our failures of mind, we may suitably dub it a metaliability. As such, it gives us half the story of the ease with which we turn a blind eye to our cognitive limitations: In particular, it tells how we turn a blind retrospective eye. Precommitment is the strategy by which we turn a blind prospective eye.

of feasibility can be manipulated by adding or subtracting from the agent's knowledge of the objective conditions of his world.

Decision theorists have coined the expression "Buridan's Ass" to describe a situation in which an agent is immobilized because he prefers all the available options equally and thus cannot decide between them. The agent may value them all equally because he does not have the information needed to distinguish between them or because there is no objective difference between them. The expression comes from an example used by the medieval scholastic, Jean Buridan, in which an ass starves to death because it cannot decide which of two identical piles of hay it should eat. As for the problem of honing down an infinitude of options without actually evaluating them, Daniel Dennett has discussed this matter in cognitive-scientific terms as the "frame problem." Dennett, Cognitive Wheels: The Frame Problcm in AI, in Minds, Machines, and Evolution 129-52 (C. Hookway ed. 1984).

51. J. Elster, Sour Grapes (1983) (studying sour grapes); J. Elster, UlysSes aNd THE SIRENS (1979) (studying precommitment). The cognitive limits exposed by sour grapes and precommitment undermine the psychological viability of utilitarianism as a theory of social choice. Specifically, it shows that the desirability of some state of affairs is intrinsically bound up with the perceived probability of its occurrence. This connection serves to call into question the concept of "expected value" found in decision theory, on which quantitative versions of utilitarianism rely, since that concept presupposes that you can measure the extent to which you expect something to happen independently of the extent to which you want it to happen. From an historical perspective, this predisposition to react positively to whatever happens may be explained as an instance of sour grapes. For more on the "subversion of rationality," especially regarding incrementalist reasoning, see R. GoodrN, Political Theory and Public Policy 19-38 (1982). 
This is the metaliability that lets us think that we act more often to benefit our interests than we really do. The most notorious cases work by a "self-fulfilling prophecy." Specifically, our desire for some end "precommits" us to interpreting all subsequent events-however unpalatable they may seem in their own right-as positively contributing to that end. A vivid example is the extent to which the early economic hardships of the Soviet Union were ideologically converted into tests of fortitude for the Russian people, specifically into tests of their willingness to relinquish fully their pre-socialist ways. Like sour grapes, the net effect of this strategy is to make us settle for less when more was originally intended, which serves to instill a spurious sense of self-control over the human condition. $^{.2}$

52. Roberto Unger is probably responsible for much of the insensitivity that CLS members have displayed toward precommitment and sour grapes. Precommitment may naturally emerge as a cognitive "defense mechanism" for long-term, large-scale projects in which there is likely to be much dispersed effort along the way. This dispersion of effort could give the ir.pression that the project has divaricated from its original course. But, in addition, such a mechanism can be deliberately deployed, as in the case of a scientist who refuses to give up a theory simply because of a few initial falsifying instances. As Imre Lakatos has pointed out in arguing against Karl Popper, if scientists regularly responded to negative feedback by altering their theories, it would be difficult for revolutionary breakthroughs to occur. A scientific revolution is usually based on a theory that was "born refuted," in the sense that the very conception of evidence did not originally lend itself to interpreting empirical results in a manner conducive to the theory. Consequently, the would-be revolutionary is advised to stick to his theory until the falsifications start to become overwhelming. See Lakatos, Falsification and the Methodology of Scientific Research Programmes, in Criticism AND THE Growth OF KNOWLEDGE 91-199 (I. Lakatos \& A. Musgrave eds. 1970). In contrast to this strategy, consider the following remark of Unger's:

To engage in [the internal development of our social ideals] self-reflectively you need make only two crucial assumptions: that no one scheme of association has conclusive authority and that the mutual correction of abstract ideals and their institutional realizations represents the last best hope of the standard forms of normative controversy.

R. UNGER, supra note 46 , at 18 , quoted in Singer, supra note 2, at 65 . It would seem that Unger would have us grant legal facts and legal theories the same status in this dialectical, or (as Rawls would put it) "reflective equilibrium," process. For reasons analogous to the science case, and notwithstanding CLS hints to the contrary, it is difficult to see how any sort of radical social change could come from such epistemic evenhandedness. This is just one of many examples in which Unger portrays a debate or conflict as consisting of two equally weighted sides. It is little more than a Hegelian mannerism, but it serves to distort the CLS sense of causation in the social world. Perhaps the most notorious case concerns "Self" versus "Structure," which has been especially exploited (with the aid of Sartre's Critique of Dialectical Reason) by Peter Gabel. See Gabel, Intention and Structure in Contractual Cultures: Outline of a Method for Critical Legal Theory, 61 MiNn. L. REv. 601 (1977). This viewpoint also receives the endorsement of Boyle. See Boyle, supra note 13, at 718-21; Singer, supra note 2, at 40-45.

For Unger, Gabel, Boyle, and Singer, "Self" and "Structure" (like the correlative "local" and "global") stand for, respectively, the individual and society - but with a German idealist twist, since the distinction is drawn entirely from Self's (first-person) standpoint. Consequently, Structure is evepything that limits Selfs existence: What is not directly determined by Structure is open for determination by Self, and vice versa. Now, what is the evidence for the existence of this overbearing Structure? Unger and the rest seem to rely on only two sources: the uniformity of legal language and the frequent frustration of SelPs interests. What is missing here-and normally present in social scientific accounts-is a causal explanation for Structure's resistance to Self's initiatives. After all, social structures may not be so resistant to change if individuals have a competent understanding of how they work. Short of such an understanding, however, these individuals can easily end up undermining their own efforts and magnifying the apparent stability of the social structures, by misinterpreting their ignorance as signs of active social resistance-yet another case of the antirealist reifying what is, in fact, the product of our cognitive limitations. French sociologist Raymond Boudon has some especially 
Turning finally to consensus formation, we find that there seems to be no real difference between Singer and Stick, except (so claims Stick) that Singer misses the fact that Rawls, Dworkin, and the other recent liberal theorists would agree with Stick and Singer. ${ }^{53}$ Given the affinity noted earlier between liberalism and antirealism in general, Stick's conclusion should not come as a surprise. But (no surprise here either) there are problems. Here is Richard Bernstein's statement of this viewpoint on consensus, which Singer quotes approvingly:

Democratic politics is an encounter among people with differing interests, perspectives, and opinions-an encounter in which they reconsider and mutually revise opinions and interests, both individual and common. It happens always in the context of conflict, imperfect knowledge, and uncertainty, but where community action is necessary. The resolutions achieved are always more or less temporary, subject to reconsideration, and rarely unanimous. What matters is not unanimity, but discourse. ${ }^{54}$

Given his opening remarks, Bernstein's conclusion is perverse, if not downright false. He skirts around a rather obvious fact about consensus formation, namely, that it functions much as precommitment does-by binding the will of people who would otherwise proceed in disparate ways, as factions within the larger "democratic" community. This is certainly the idea behind having elected representatives who speak on behalf of an entire constituency. The fact that people continue to go their way, even against the will of their representative, is at least as much due to the representative's cognitive inability to monitor what the people are thinking as to their actually changing their minds. Indeed, the preponderance of "second-order" ignorance that members of a community have about what one another thinks accounts for the volatility of public opinion, especially in democratic societies. ${ }^{55}$ To think, as Bernstein does, that consensuses are unstable primarily because of the "first-order" ignorance that people have about their own future wants and needs is to presume that second-order ignorance is largely unproblematic, as it can be readily corrected through face-to-face encounters in the "forum."

wise things to say on these matters. See Boudon, The Logic of Relative Frustration, in RATronAL. CHOrce, supra note 38 , at $171-96$.

53. Stick, supra note 2 , at 383 .

54. R. BERNSTEIN, supra note 15 , at 223 , quoted in Singer, supra note 2 , at 64.

55. One way in which mass democracies undergo major shifts in opinion without design is by the spiral of silence, a process familiar to public opinion pollsters. Since people in a democracy presume that everyone has equal access to the means of communication, the opinions openly expressed tend to be taken as representative of the ones actually held. Consequently, if a dominant position is attacked by a fairly vocal minority, and no response is forthcoming, support will start to shift from the dominant to the minority position. See E. Noelie-Neumann, The Spiral of Silence (1982). John Maynard Keynes famously noted a similar tendency in stock market speculations. J. KEYNES, THE GenERAl. TheORY OF EMPLOYMENT, INVESTMENT, AND MONEY 147-64 (1964).

56. Some scholars have suggested that the very idea of a consensus is a myth. See B. FAY, CRITI- 
tion of this Comment such a presumption is both epistemically and politically wrong-headed.

\section{Conclusion: Realism and Political Metatheory}

What, if any, are the implications of scientific realism for the evaluation of political theories? This is the question of metatheory, to which I now turn. First, we need to reclaim irrationalism from Singer's antirealism, which is most evident in the four aims of political reform to which he would apply legal means. ${ }^{57}$ The four aims - to prevent cruelty, to alleviate misery, to democratize hierarchies, and to eliminate loneliness-are unobjectionable in their own right, even admirable. What is objectionable, however, is Singer's apparent assumption that because CLS has shown that legal decisionmaking is not governed by determinate rules, it follows that legislators and judges can deliberately bring into existence a consensually desirable social order. Admittedly, this assumption seems rather innocuous-that is, until we consider that certain surts of outcomes are rendered less likely, and perhaps even impossible, when pursued as deliberate goals. Only a trenchant sense of social antirealism would claim as a general principle, "where there's a will, there's a way" or "the direct route is the best route." Moreover, as I shall now sketch, this sense of social antirealism has been historically informed by a fear of human cognitive fallibility. ${ }^{58}$

Take Aristotle's original conception of political rationality, phronesis, of which so much has been made in recent years by Gadamer, Habermas,

Cal. Social Science 165-202 (1987). Thompson has argued that recent studies in public discourse suggest that societies coalesce, not around values or ideas, but around contained areas of disagreement. Thompson's conclusion is that the glue binding societies together is, in short, the acceptance of dissensus. J. Thompson, supra note 50 , at 5.

Even if we were to grant the appropriateness of the Athenian forum as the model for consensus formation in mass democracy, there would still be the question of the "epistemic rights" of the participants. See infra note 62 . R. RoRTY, supra note 12 , runs together three incompatible ways of allocating epistemic rights:

(1) Equal-Time Liberalism: The doctrine that efforts should be taken to ensure that all parties to the conversation are always on the same footing, no matter what transpires in the course of the conversation, even if it includes a radical change in the attitudes that the parties have toward one another.

(2) Separate-but-Equal Liberalism: The doctrine that since a viewpoint is valid for the culture from which it arose but invalid (or at least inappropriate) for any other culture, it follows that efforts should be taken to protect the viewpoint of a culture from extra-cultural interference.

(3) Equal-in-Principle Liberalism: The doctrine that since all viewpoints are "created equal," in the sense that none has any a priori advantage over the rest, it follows that whatever success that particular viewpoints turn out to have in history will be solely the result of their having adapted to contingencies in the marketplace of ideas.

Unger is generally as vague as Rorty on these matters, though at one point he says that political empowerment is designed to recover the liberal ideal (most clearly associated with the marketplace) of all social interests bearing an equal burden of risk. R. UNGER, supra note 46, at 102.

57. Singer, supra note 2 , at $66-70$.

58. The following historical account is taken in large measure from F. HAYEK, New STUDIES IN Philosophy, Economics, AND THE History of IDEAs 72-97 (1978). 
and Bernstein. ${ }^{59}$ It is common nowadays to construe phronesis as the open-textured rules that enable the play of political language games in a community. The sense of openness that Aristotle reserved for politics had less to do with its status as a social construction than as an activity whose complexity made its practitioners prone to error. Moreover, cognitive safety was not to be found in political numbers, since Aristotle's conception of public opinion, doxa, was expressly defined in terms of its fallibility (but also its corrigibility). All this changed, however, at the start of the modern era, when philosophers began to collapse the Aristotelian distinction between a divine order that people "found" (cosmos) and a human order that was "constructed" (taxis). Consequently, as in the case of Hobbes's social contract theory, it was no longer presumed that order would exist in the world without explicit human intervention.

It should perhaps come as no surprise that once humans started acquiring qualities formerly reserved for God, philosophers became dissatisfied with simply learning to work around, and perhaps partially alleviate, human fallibility. Rather, fallibility had to be denied, or at least infallible domains of reasoning had to be found. Descartes expressed this dissatisfaction most famously in his search for rational foundations for knowledge, but by the eighteenth century it had made its way into political theory. The route required the following turns:

(1) Descartes' argument, "I think therefore I am," was widely taken to imply that if there is any knowledge at all, there is selfknowledge.

(2) The most reliable form of self-knowledge does not involve reference to anything outside the self, such as physical causes and effects, which could be subject to manipulation from an unknown source.

(3) Thus, the most likely candidate for an infallible domain of reasoning would issue in judgments of one's own self-generated desires.

(4) The aggregation of these infallible judgments would itself be infallible and thereby provide the most legitimate basis for decisive social action.

This line of reasoning was embodied in Rousseau's volonté générale and was eventually used to legitimate the French Revolution of 1789. As an argument, the reasoning is flawed by the fallacy that just because you know what you want, it does not follow that what you want will turn out as you expect. I have already suggested that Singer may be guilty of this fallacy. However, making the charge stick on anyone these days is a tricky business, given the often self-fulfilling character of democractic political

59. R. BERNStEIN, supra note 15, at 171-232 (discussing Gadamer and Habermas). 
reasoning. For example, such terms as volonté générale and vox populi are often used indiscriminately for both a state of knowledge (of what The People want) and a state of power (to bring about what The People want), especially when the particular political theorist wants to justify the use of any means, for as long as it takes, to bring about the desired ends. Under those conditions, the failure of expectations to match intentions simply means that more force needs to be applied. ${ }^{60}$ Such is the extent to which humans have gone to avoid admitting that their political knowledge is as fallible as their scientific knowledge.

In contrast, the political metatheory of irrationalism that I am proposing originated with Machiavelli and culminated at the turn of the century with the work of Georges Sorel, Vilfredo Pareto, and Roberto Michels. ${ }^{61}$ Its fundamental precept is that no political theory or program should be accepted unless it somehow takes into account the cognitive liabilities of the large numbers of people who would function as governors and governed. Although irrationalism is traditionally seen as postulating unconscious emotive mechanisms, so-called passions or instincts, as responsible for these liabilities, this aspect of the metatheory has not been as systematically developed as its general skepticism toward the efficacy of deliberative reasoning as a political medium in large heterogeneous democratic societies. In the first attempt to carve out a modern sense of politics, Machiavelli realized that the two classical instruments of power, coercion and persuasion, would not work without substantial modification. Coercion would not work because developments in the art and artifacts of warfare have enabled disputing parties, with the help of minor miscalculations, to annihilate each other. But neither would persuasion work, for democracies are dominated by competing factions that ultimately respond to mutually incompatible arguments. Moreover, there would never be sufficient closure on debate for policy decisions to be made, if the Athenian forum were reproduced en masse so as to permit people the opportunity to weigh the merits of the respective interests.

For better or worse, manipulation turned out to be the Machiavellian via media between the inadequacies of coercion and persuasion. However,

60. Georges Sorel was a student of the opposite and equally pernicious tendency, which also nicely captures the cycle of sour grapes-and-precommitment. See supra text accompanying note 51. This is the fallacy of optimism, whereby initial success leads to a lessening of force. In the give-andtake of democratic politics, it is common for a party to interpret a minor legislative victory as vindicating its general policies, and then to follow up this alleged vindication, not advancing by legislative proposals more central to a party's platform, but by advocating measures intended to appease the opposition parties. While leaders of the victorious party like to make it seem as though they act this way out of a democrat's sense of noblesse oblige, such behavior also conveniently prevents any clear test of the party's mandate. See G. SOREL, REFlections on ViolenCE (1912). Singer's obliviousness to the way that intentions, expectations, and outcomes feed on each other is clear from his discussion of "ends." Singer, supra note 2, at 61-62.

61. A good account of the intellectual and cultural context of these three fin de siecle Machiavellians is H. Hughes, Consciousness and Society: The Reconstruction of European Social Tноught, 1890-1930, at 161-82, 249-77 (1958). 
by treating irrationalism as political metatheory, we need not so much endorse Machiavelli's own politics as the considerations that he took to be necessary for framing an adequate politics. And it is in this light that we should once again consider the efficacy of deliberative reasoning in contemporary democracies.

One great liberal who has been conspicuously absent from the recent debates over legal theory is John Stuart Mill, perhaps the staunchest defender of rational deliberation as a political medium in the modern period. However, unlike Rorty, Bernstein, and other members of "the conversation of mankind" school of politics, Mill did not defend deliberation primarily by appeal to freedom of expression, human rights, or other edifying grounds. ${ }^{62}$ Rather, Mill made the classical argument that rational deliberation in an open forum promotes the mutual criticism of claims, which is the most efficient means of eliminating undesirable or otherwise inoperable proposals, which in turn improves the actions taken by both the individual and the state. In short, Mill presented a model of politics as inquiry, with the common good playing the role of truth. More interesting from a metatheoretic standpoint, however, is that Mill has provided a theory based on empirically testable claims about the ideal modes of producing and distributing knowledge in liberal democracies. ${ }^{63}$ As such, it is open to the realist inquiry raised in this paper and the uncomfortable answers that are likely to result.

62. J. MnL, ON LiBERTY, ch. 2 (1859). The great need for political "conversation" felt by Bernstein, Rorty, Dworkin, Singer, Stick, and CLS may be seen as the result of the Platonic ideal of social harmony having been filtered through antirealism. A characteristic statement is Boyle, supra note 13, at $762-78$.

As Rorty has pointed out, see R. RoRTY, supra note 12 , at 264 , the idea of rehabilitating lost voices in "the conversation of mankind" was introduced by the cultural conservative Michael Oakeshott in the context of accrediting poetry as a "mode of experience" on equal footing with philosophy, science, history, and the other disciplines. M. OAKESHOTT, supra note 21.

From a realist standpoint, this would seem to confuse the rights that people have as political agents with their rights as epistemic agents. As epistemic agents, people have the right to a fair test of their beliefs, but not a right to have those beliefs entertained in perpetuity, even if they are beliefs about the political status of the epistemic agents. Indeed, the possibility of eliminating error was the big advantage that John Stuart Mill saw in conducting politics in an open forum. The failure to sort out political from epistemic rights is also evident in the CLS tendency, most pronounced in Boyle and Unger, to take the subjective experience of social dislocation and objectivist theories of social order as being on an irreducibly equal epistemic footing. In contrast, a realist would want to account for the phenomena to which each perspective has special access without necessarily having to endorse the epistemic status of either (and certainly not of both).

63. The more left wing followers of Karl Popper have long noted Mill's epistemic politics. W. Albury, The Politics of Objectivity (1983); P. Feyerabend, Problems of Empiricism 65-79 (1981). Interestingly, Singer cites Mill only once, and for other purposes, see Singer, supra note 2, at 16 n.46, while Stick the liberal does not mention Mill at all. 